\title{
European Political Trends Viewed Through Patterns of Web Linking
}

\author{
Esteban Romero-Frías ${ }^{\mathrm{a}, ~}{ }^{*}$, Liwen Vaughan ${ }^{\mathrm{b}}$ \\ ${ }^{a}$ Department of Accounting and Finance, University of Granada, Spain \\ Campus Universitario de Cartuja, 18071, Granada, Spain. Phone: (+34) 958241000 ext. 20161. Fax: \\ (+34) 958246249, erf@ugr.es \\ ${ }^{b}$ Faculty of Information and Media Studies, University of Western Ontario, Canada \\ Faculty of Information and Media Studies, University of Western Ontario, London, Ontario, N6A 5B7 \\ Canada. Phone: 519-661-2111 ext. 88499, lvaughan@uwo.ca \\ ${ }^{*}$ Corresponding author.
}

\begin{abstract}
This study explored the feasibility of using Web hyperlink data to study European political Web sites. Ninety-six European Union political parties belonging to a wide range of ideological, historical and linguistic backgrounds were included in the study. Various types of data on Web links to party Websites were collected. The Web co-link data were visualized using multidimensional scaling (MDS) while the inlink data were analyzed with a two-way analysis of variance test. The results showed that Web hyperlink data did reflect some political patterns in the European Union (EU). The MDS maps showed clusters of political parties along ideological, historical, linguistic and social lines. Statistical analysis based on inlink counts further confirmed that there was a significant difference along the line of the political history of a country, such that left-wing parties in the former communist countries received considerably fewer inlinks to their Websites than left-wing parties in countries without a history of communism did. The study demonstrated the possibility of using Web hyperlink data to gain insights into political situations in the EU. This suggests the richness of Web hyperlink data and its potential in studying social-political phenomena.
\end{abstract}

Keywords Internet politics, Web data mining, co-link analysis, Webometrics 
Romero-Frías, E. \& Vaughan, L. (2010). "European Political Trends Viewed Through Patterns of Web

Linking”. Journal of the American Society for Information Science and Technology, 61(10): 2109-2121. Postprint for research purposes.

\section{Introduction}

In the past ten years Internet politics have become part of the social science mainstream (Chadwick \& Howard, 2009). The Web is increasingly used for political and social purposes and consequently has become an object of study in social sciences. In information science, Webometrics methods have been used to explore the social and political dimensions of the Web. For instance, Vaughan and Zhang (2007) examined the search engine coverage of Websites from different countries to explore possible biases and their implications; Gao (2009) analyzed Web server logs of China's largest online newspaper to gauge the public's political sentiment; Thelwall and Vaughan (2004) investigated the Internet archive to find out whether the Web history of different countries was fairly represented there; Bar-Ilan and Echerman (2005) examined the Web linking patterns related to the political event of anthrax scare; and Holmberg (2009) analyzed Web hyperlink patterns to study cooperation and geopolitical connections among regional governments in an area of Finland.

Building on these earlier studies, the current study examined patterns of Web linking to Europe's political parties to find out if and how information gained from Web data reflects Europe's political trends. The study included the main political parties of the European Parliament (EP). The current study differs from earlier ones in that it examines a large number of parties with diverse political orientations and social, historical backgrounds. The complexity of the political phenomena was both a challenge and an opportunity for the study. The 2009 election of the EP provided an opportunity for this kind of study, as the political parties all have a Web presence and increasingly use the Web for campaigning. Our research questions are:

Do Web link data effectively reflect the main political relationships in the European Union?

Can the relative positions of political parties visualized through Web hyperlink data be explained in terms of ideological, historical, linguistic and social variables? 
Romero-Frías, E. \& Vaughan, L. (2010). "European Political Trends Viewed Through Patterns of Web Linking”. Journal of the American Society for Information Science and Technology, 61(10): 2109-2121. Postprint for research purposes.

The political parties in the study represent the most important political trends in Europe, in a context in which varied social, cultural, linguistic and historical backgrounds are present. We collected both inlink and co-link data to Websites of these parties and analyzed the data using multidimensional scaling (MDS) and other methods. An inlink is a hyperlink embedded on one page that points to another page. For example, if there is a hyperlink on page $\mathrm{Z}$ that points to page $\mathrm{X}$, then page $\mathrm{X}$ has an inlink. If both page $\mathrm{X}$ and page $\mathrm{Y}$ receive inlinks from page $\mathrm{Z}$, then page $\mathrm{X}$ and page $\mathrm{Y}$ are co-linked. Co-link counts as a measure of relatedness between co-linked entities have been used successfully to analyze business sites (Vaughan \& You, 2006, 2008), university sites (Thelwall \& Wilkinson, 2004) and government sites (Holmberg, 2009).

In this study, we first looked at the general picture of the political parties belonging to distinct political groups, and then focused on the two most prominent groups representing the right and left sides of the political spectrum. The political history of a country - specifically, whether or not it was a former communist country - was a factor that was specifically analyzed and found to be an important variable in explaining the linking pattern.

\section{Literature Review}

Although research on Internet politics has been carried out in different areas, this section focuses on some of the main issues that could be relevant to an analysis of political trends in the European Union. Burt and Taylor (2001) suggest that the ways in which technologies are exploited are influenced by social conditions, philosophies and value systems. Ward and Gibson (2009) add the framework of the political system as an additional relevant factor. March (2006) suggests that newer democracies in which political communication and political systems are less fixed and developed could allow a greater role for new 
Romero-Frías, E. \& Vaughan, L. (2010). "European Political Trends Viewed Through Patterns of Web Linking”. Journal of the American Society for Information Science and Technology, 61(10): 2109-2121. Postprint for research purposes.

technologies. This could be the case in Eastern European countries where democratic systems are very recent as a result of the past communist domination.

E-campaigning and e-mobilization are also important areas of research, as the Internet has been posited as a powerful tool to mobilize people. However, some studies in the United States (Gibson et al., 2003, 2005) and Europe (Norris, 2003) show that many visitors to political sites are already politically active. Web 2.0 has also arisen as a relevant subject in the development of Internet politics (Chadwick \& Howard, 2009).

Some research (Kluver et al., 2007; Davis et al., 2008) has focused on political parties in the national electoral context. Regarding the analysis of European parties, it is worth mentioning that Norris (2003) analyzed 134 party Websites from 15 Member States in the EU and provided an analysis based mainly on Website contents and design. The green parties are at the top of the ranking in Norris' study followed by these other groups: far right, conservative and right-wing parties, center, social-democrats, liberal and extreme left.

This paper applies both inlink and co-link analysis to heterogeneous groups of political parties. This heterogeneity implies that there are many factors that can influence parties' positions in the European political spectrum. These factors range from the level of Internet access in a particular country or region to the various political, cultural, historical and social contexts of the different countries (van Dijk, 2009). Earlier studies also used Web link data to study political and socio-economical phenomena. The triple helix model (Etzkowitz \& Leydesdorff, 1997) refers to the analysis of knowledge-based innovation systems through the interconnections between three institutional spheres: university, industry and government (Leydesdorff \& Meyer, 2003, 2007). Some research (Stuart \& Thelwall, 2006; GarcíaSantiago \& de Moya-Anegón, 2009) used Web link data to visualize these connections. 
Romero-Frías, E. \& Vaughan, L. (2010). "European Political Trends Viewed Through Patterns of Web

Linking”. Journal of the American Society for Information Science and Technology, 61(10): 2109-2121. Postprint for research purposes.

\section{An overview of the European Union political system}

A brief overview of the European Union (EU) political system is provided here to aid the understanding of the current study's context and results. The European Union is a supranational organization whose Member States are independent nations that pool their sovereignty in order to gain more influence in the international context (European Parliament, 2009; European Union, 2009). The European Parliament is the only institution in the EU whose members are democratically elected every five years by direct universal suffrage. The EP is made up of 736 Members elected in 27 Member States. The seats are, as a general rule, allocated to Member States in proportion to population. The Members of the European Parliament are grouped by political affiliation rather than nationality. There are currently seven political groups in the European Parliament. Members may not belong to more than one political group. Some Members do not belong to any political group and are known as non-attached Members. Twenty-five Members are needed to form a political group, and at least one-quarter of the Member States (currently seven countries) must be represented within a group.

The political groups in the EP play a significant role in the functioning of the institution. Outside the EP, political parties also exist at the European level. These political parties and political groups are composed of national parties and individuals as members. In practice, the political groups within the EP are supported by the political parties at the European level. The former carry out political initiatives within the European Parliament, while the latter coordinate political will at the European level. This study focused on political parties as the units of analysis; therefore, we took into account the political parties at the European level rather than considering the political groups in the EP. However, both types of entities are strongly connected and often have the same name. In order to select the parties within the study, we focused on the seats obtained by each national party in their own country. These parties and their members in the EP belong simultaneously to a political group and to the corresponding political party at the European level. 
Romero-Frías, E. \& Vaughan, L. (2010). "European Political Trends Viewed Through Patterns of Web Linking”. Journal of the American Society for Information Science and Technology, 61(10): 2109-2121. Postprint for research purposes.

It is worth noting that the largest groups in the EP, both currently and historically, are the Group of the European People's Party (the related party is the European People's Party, EPP) and the Group of the Progressive Alliance of Socialists and Democrats in the European Parliament, S\&D (the related party is the Party of European Socialists, PES; this group was previously named "Group of the Party of European Socialists" and also "Socialist Group in the European Parliament"). For the sake of clarity, S\&D will be referred to as PES.

\section{Methodology}

\subsection{Selection of political parties to study}

All national political parties represented in the June 2009 elections of the European Parliament (EP) were candidates in the study. Due to the high number of parties and groups in the EP, this study focused on the two largest groups: EPP and PES (S\&D) (see Table 1). To analyze the overall situation, we also considered other major national parties and the European level parties (ALDE, GREENS and ECR). These five groups represent $87.2 \%$ of EP members. Due to the small size of the GUE/NGL group, only the European level party was included in order to situate the group within the context of the other European parties. The EFD Website was under construction at the time of data collection so it was not included in the study.

Table 1. Composition of the EU Parliament as a result of the 2009 European Elections

\begin{tabular}{|l|l|l|}
\hline Political group $(*)$ & Number of seats & Percentage of seats \\
\hline EPP (A) & 265 & 36 \\
\hline PES (B) & 184 & 25 \\
\hline ALDE (C) & 84 & 11.4 \\
\hline GREENS/EFA (D) & 55 & 7.5 \\
\hline ECR (E) & 54 & 7.3 \\
\hline
\end{tabular}


Romero-Frías, E. \& Vaughan, L. (2010). "European Political Trends Viewed Through Patterns of Web

Linking". Journal of the American Society for Information Science and Technology, 61(10): 2109-2121. Postprint for research purposes.

\begin{tabular}{|l|l|l|} 
GUE/NGL (F) & 35 & 4.8 \\
\hline EFD & 32 & 4.3 \\
\hline NA & 27 & 3.7 \\
\hline Total & 736 & 100 \\
\hline
\end{tabular}

EPP: Group of the European People's Party (e.g. Christian Democrats).

PES: Since the elections of June 2009, the PES group in the EP is called "Group of the Progressive Alliance of Socialists and Democrats in the European Parliament".

ALDE: Group of the Alliance of Liberals and Democrats for Europe.

GREENS/ EFA: Group of the Greens/European Free Alliance.

ECR: European Conservatives and Reformists Group.

GUE/NGL: Confederal Group of the European United Left - Nordic Green Left.

EFD: Europe of Freedom and Democracy Group.

NA: Non-attached.

$\left(^{*}\right)$ means the label to identify the parties at European level and the national parties belonging to the corresponding family.

The composition of the parliament, as shown in Table 1, corresponds to the Incoming Parliament (Constituent) of the seventh legislature (2009-2114). Changes are expected after the approval and application of the Lisbon Treaty.

The complete list of the parties in the study is included in Appendices A, B and C to facilitate the understanding of the findings in Figures 1 and 2. Appendices include the following information: label in the MDS maps, name, abbreviation and URL of the political party, the number of seats in the EP, and the number of inlinks pointing to the Website. Composition of the political groups was taken at the end of July 2009 from an EP Website

(http://www.europarl.europa.eu/parliament/archive/elections2009/en/new_parliament_en.html).

In order to facilitate the identification of political parties, the party labels in the MDS maps are made up of a capital letter indicating the political family followed by the country code (the top-level domain used on the Internet). The full list with labels can be found in the Appendices. If a country has more than one 
Romero-Frías, E. \& Vaughan, L. (2010). "European Political Trends Viewed Through Patterns of Web

Linking”. Journal of the American Society for Information Science and Technology, 61(10): 2109-2121. Postprint for research purposes.

party in the EP, the label is followed by a number, with 1 being the political party that obtained the highest number of seats.

Each party's Website address was collected from the directory of each party at the European level and manually checked to ensure its correctness. The vast majority of parties in the study have only one URL for their Websites and use their own country code for the top-level domain. When a coalition of parties took part in the elections, usually there was no separate Website for the coalition; therefore, the party with the most inlinks was selected for the study. For the few that have alternative URLs in the form of an alias or redirect, we checked each URL to determine which one had more inlinks and used that one to collect inlink data. We considered including both URLs in data collection; however, Yahoo!, the search engine used for data collection, cannot handle the complex query syntax for collecting co-link data using two URLs.

\subsection{Collection of Web link data}

Of the three major search engines, Google, Yahoo! and MSN Bing, only Yahoo! could be used for data collection for the study. Google's inlink search only returns a sample of all inlinks that the Google database records (Google, 2009). In addition, Google cannot filter out internal inlinks (inlinks originating from within the Website itself, such as "back to home" links) as the query term "link" cannot be combined with any other query terms (Google, 2006). In other words, Google cannot report the external inlink counts required for the study. MSN Bing (formerly MSN Live Search) used to have inlink search functions but the service was turned off around March 2007 (Live Search, 2007). At the time of data collection, summer 2009, Yahoo! was the only option for collecting the inlink data required for the study.

Because search engines from different countries may have databases that favor Websites from the host country (Vaughan \& Thelwall, 2004), we considered using the country-specific version of Yahoo! to retrieve inlinks to the political parties from that country. However, tests of some country-specific versions 
Romero-Frías, E. \& Vaughan, L. (2010). "European Political Trends Viewed Through Patterns of Web Linking”. Journal of the American Society for Information Science and Technology, 61(10): 2109-2121. Postprint for research purposes.

of the search engine, such as the Spanish, French, and UK versions of Yahoo!, returned the same inlink search results as the global version of Yahoo!. Unlike the Chinese version of Yahoo!, which has a database that is different from that of the global version of Yahoo!, these country-specific versions of Yahoo! had a different interface but the same underlying database. So the global version of Yahoo! (www.yahoo.com) was used for all data collection through the application programming interface (API).

Yahoo! has two inlink search query terms, "link" and "linkdomain". The "link" query term finds links to a particular page (e.g., link:http://www.abc.com finds links to the homepage of www.abc.com) while the "linkdomain" query term retrieves all links that point to all pages of a particular Website or domain, including the homepage. We used the "linkdomain" query term for data collection because all links, not just links to the homepage, are relevant to the study. The query syntax for the data collection is illustrated in Table 2 using the example URLs www.abc.com and www.xyz.com. We truncated the www portion of the URLs in the queries to capture links to all subdomains such as mail.abc.com. The "-site:abc.com" part of the query filters out internal links coming from within the domain of abc.com itself.

Table 2. Illustration of Yahoo! Queries for Data Collection

\begin{tabular}{|l|l|}
\hline \multicolumn{1}{|c|}{ Types of links searched for } & \multicolumn{1}{c|}{ Query } \\
\hline Inlinks to www.abc.com & linkdomain:abc.com -site:abc.com \\
\hline $\begin{array}{l}\text { Co-links between } \\
\text { www.abc.com and } \\
\text { www.xyz.com }\end{array}$ & $\begin{array}{l}\text { (linkdomain:abc.com -site:abc.com) } \\
\text { (linkdomain:xyz.com -site:xyz.com) }\end{array}$ \\
\hline
\end{tabular}

Since co-links involve a pair of Websites, the co-link data are collected in the form of a matrix with row $\mathrm{x}$ and column y of the matrix representing the number of co-links between URL $\mathrm{x}$ and URL $\mathrm{y}$. We collected two sets of co-link data: one including all of the political families in the EP and one including only EPP and PES parties. 
Romero-Frías, E. \& Vaughan, L. (2010). "European Political Trends Viewed Through Patterns of Web

Linking”. Journal of the American Society for Information Science and Technology, 61(10): 2109-2121. Postprint for research purposes.

\subsection{Methods of data analysis}

Each co-link matrix was analyzed using multidimensional scaling (MDS) to generate an MDS map. MDS uses a heuristic method to place parties with higher co-link counts closer together in the resulting MDS map. Since similar or related parties are more likely to receive co-links, the number of co-links between a pair of political parties is a measure of their relatedness. Therefore, similar or related political organizations will be placed closer together in the MDS map. The positions of the parties in the map reveal only their relative relationship to each other. We hoped to use the MDS map to see clusters of parties that would reveal their ideological positions, as well as geographical, linguistic and social features.

\section{Results}

In this section we present an analysis of the overall positioning of the most relevant national and European parties and a comparison between the two largest groups, EPP and PES (S\&D). Limitations and future research prospects are discussed in the next section. The current study analyzes heterogeneous parties in terms of their ideology and country; therefore, our first expectation is to find clusters of similar parties, that is, parties belonging to the same political family and country are expected to be grouped in the MDS maps.

\subsection{All political groups}

This section analyzes the plurality of ideologies in the EP. Accordingly, an MDS map showing parties belonging to the five largest groups in the study is presented (see Figure 1). Including all of the parties would result in a concentration of data points in the MDS map that would make interpretation unfeasible. Therefore, only parties belonging to the EU 12 (the first twelve Member States of the European Union) and with more than one seat in the parliament are considered. EU 12 includes some of the most important countries in terms of historical, political and economic influence. The EU 12 countries are Belgium, Denmark, Germany, Greece, Ireland, Italy, France, Luxembourg, Netherlands, Portugal, Spain, and 
Romero-Frías, E. \& Vaughan, L. (2010). "European Political Trends Viewed Through Patterns of Web Linking”. Journal of the American Society for Information Science and Technology, 61(10): 2109-2121. Postprint for research purposes.

United Kingdom. In addition, GUE/NGL ( $\mathrm{F}$ in the map) as a European level party is included. These criteria reduce the number of parties in the map to 50, which includes most of the influential parties in the EU. Aie, the conservative Irish party, had no co-links with most parties so it was excluded from the analysis. The stress value of the MDS analysis of Figure 1 is 0.07 , which is fairly low and suggests a good fit between the map and the data.

FIG. 1. MDS map for all political groups

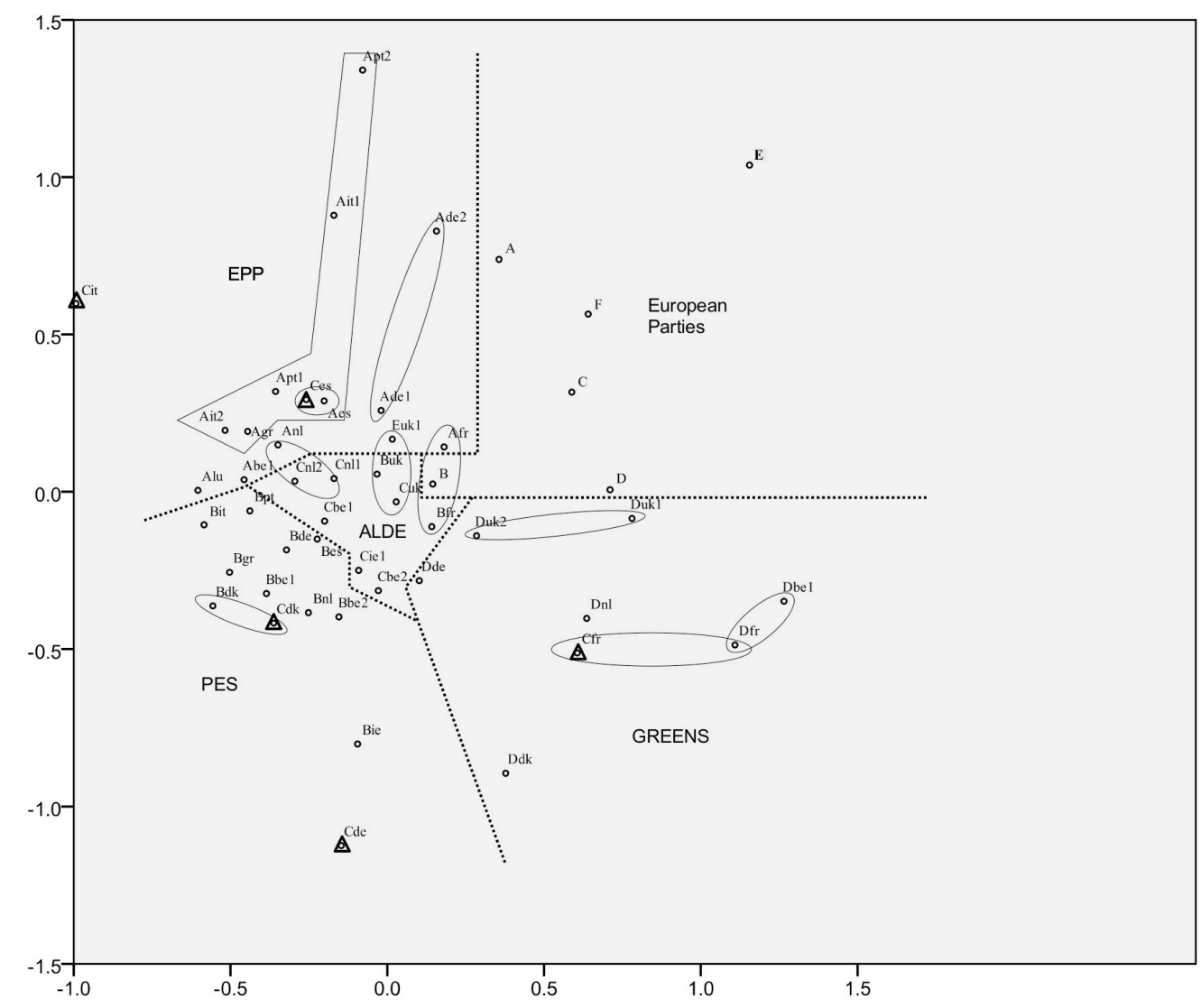

Figure 1 shows five clusters of parties. With a few exceptions, parties belonging to the same political group are located in the same cluster. To make the interpretation clearer, we will only comment on 
Romero-Frías, E. \& Vaughan, L. (2010). "European Political Trends Viewed Through Patterns of Web

Linking”. Journal of the American Society for Information Science and Technology, 61(10): 2109-2121. Postprint for research purposes.

significant clusters in terms of geographical and linguistic similarities. The following five major party groupings are discernible based on political affiliation:

1. Political parties at the European level are shown in the upper area. This area includes the umbrella parties that integrate most of the national parties in the European Union. As coordinators of the political initiatives at the European level, they are expected to have a central position. The map shows that all of these organizations are in the same area; however, they do not form a very tight cluster. The EPP (A) and GREENS (D) parties are located relatively close to their affiliated national parties. The most noteworthy case is PES (B), which is in a central position in the map between the conservatives (EPP parties), the liberals (ALDE parties) and the greens and also close to the British and French social democrat parties (Buk and Bfr). This central position could be the result of the party's intensive work on Internet politics in recent years, in particular through the launching of the Manifesto 2009 campaign. PES is the only European party that has a central position close to parties with different ideologies. Other European parties are not as central and are close only to the parties of their own family.

2. The EPP area is located in the upper left of the map. Euk1, the British Conservative party, is located within this political group, although in this legislature they no longer belong to EPP but rather to a new political group in the EP called ECR. Ideologically, however, they are conservative and the co-link analysis correctly positioned them in this group. Ces, which stands for a Spanish coalition, is represented by the label CiU in the study. This party is a nationalist conservative Catalonian party that is close in political orientation to the PP (Aes), the main conservative Spanish party. Therefore, its position is meaningful in spite of being the only ALDE party located within the EPP area of the map. This similarity explains why the two parties are positioned very close to each other. Other national clusters, such as the Italian and German 
Romero-Frías, E. \& Vaughan, L. (2010). "European Political Trends Viewed Through Patterns of Web Linking”. Journal of the American Society for Information Science and Technology, 61(10): 2109-2121. Postprint for research purposes.

parties, are also highlighted in the map, and parties from Mediterranean countries likewise occupy the same area (Bes, Bgr, Bit, Bpt).

3. The PES area is in the lower left section of the map. The social democrat parties are grouped together in a tighter cluster than the conservative parties. This tight cluster is evidence of the higher degree of integration of the social democrat parties, which could be explained by the fact that their ideological position is based on internationalism, in contrast to the more nationalist ideologies of the conservative parties. This explanation applies to Figure 2, which will be introduced later. The British Labour Party (Buk) and the French Socialist Party (Bfr) occupy a central position outside the PES area. This positioning could be explained not only by their influence on European politics, but also by their significant Internet presence. In addition, the linguistic factor also comes into play as English and French are probably the two most important languages in the EU.

4. Parties belonging to ALDE are located at the center of the map. This reflects the party's ideological diversity, which ranges from progressive positions to conservative ones. This is also the political group with more parties scattered outside of its area (shown by triangles in Figure 1). Apart from the previously mentioned case of Ces, the Danish party, Venstre (Cdk), is located within the PES group and very close to the Danish socialist party (Bdk) and other socialist parties from neighboring countries (Bbe1 and Bbe2 of Belgium and Bn1 of Netherlands).

5. The GREENS area is located in the lower right of the map. These parties are scattered but consistently in the same area. Parties with the same language are close to each other (English speaking Duk1 and Duk2 and French-speaking Dfr and Dbe1).

The positions of two particular clusters are worth noting. These are the British and French parties in the center of the map. Their linkages are so strong that they break the ideological pattern. The British cluster 
Romero-Frías, E. \& Vaughan, L. (2010). "European Political Trends Viewed Through Patterns of Web Linking”. Journal of the American Society for Information Science and Technology, 61(10): 2109-2121. Postprint for research purposes.

comprises the Labour Party (Buk), the Conservative Party (Euk1) and the Liberal Democrats (Cuk). This central position could be explained by Britain's linguistic advantage, which results from the fact that English Webpages are accessible by a majority of users in an international context. Despite Britain's reluctance to get involved in European affairs, British politics is very relevant internationally. Moreover, the British Labour party (Buk) holds positions that are more liberal than those held by other European parties in the same group. The French cluster is made of Union pour un Mouvement populaire, UMP (Afr), and the Socialist Party (Bfr). The language and the political influence of France could explain why these parties occupy a central position together with British parties.

To further our analysis, we examined inlink counts. It is worth noting that parties in the center of the map have more inlinks, which reinforces their significance within the group. Table 3 shows the top 10 parties in terms of inlink counts. According to this impact measure, German, British, French and Spanish parties are the most relevant. The size of the country and the predominance of the English and French languages in Europe are also factors that help explain these counts. It is remarkable that only the French and British parties in the top ten list occupy a central position on the map while the Spanish and German parties do not. Again, language is a plausible explanation, as English and French are commonly used as working languages in Europe. Only one European-level party, the PES, is included in the top ten list, which means that PES attracted more inlinks than any other European-level party. In the next section, we will make a specific comparison between PES and its opponent, EPP. 
Romero-Frías, E. \& Vaughan, L. (2010). "European Political Trends Viewed Through Patterns of Web Linking”. Journal of the American Society for Information Science and Technology, 61(10): 2109-2121. Postprint for research purposes.

Table 3. Ranking of political parties with more inlinks

\begin{tabular}{|c|l|l|l|l|r|r|}
\hline $\begin{array}{c}\text { Ran } \\
\text { king }\end{array}$ & Label & Abbreviation & Name & Country & Seats & Linkdomain \\
\hline 1 & Bde & SPD & Social Democratic Party of Germany & Germany & 23 & 735000 \\
\hline 2 & Cuk & LD & Liberal Democrats & UK & 11 & 269000 \\
\hline 3 & Bfr & PS-f & Socialist Party (France) & France & 14 & 232000 \\
\hline & & & Christlich Demokratische Union & & & \\
4 & Ade1 & CDU & Deutschlands & Germany & 34 & 221000 \\
\hline 5 & Euk1 & Cons & Conservative Party & UK & 24 & 186000 \\
\hline 6 & Bes & PSOE & Spanish Socialist Workers' Party & Spain & 21 & 177000 \\
\hline 7 & Buk & Lab (UK) & The Labour Party (UK) & UK & 13 & 170000 \\
\hline 8 & B & PES & Party of European Socialists & Europe & 184 & 160000 \\
\hline 9 & Dde & GRÜNE & Bündnis 90/Die Grünen & Germany & 14 & 144000 \\
\hline 10 & Aes & PP & Partido Popular & Spain & 23 & 127000 \\
\hline
\end{tabular}

\subsection{The right wing EPP vs. the left wing PES}

EPP and PES parties took 449 out of 736 (61\%) seats in the EP. They represent the two opposite ends of a political spectrum, with EPP being the right wing and PES the left wing. They are the two most prominent parties at a European level and in most of the Member states. Historically, only these two groups have won European elections. We are thus justified in taking a closer look at these two political families by carrying out an MDS analysis just for these two groups. A total of 73 parties belong to these two groups. The MDS map would be too crowded if we included all these parties; consequently, we decided to omit fringe parties and included in our analysis only parties that have more than one seat. In addition, Aie, Aro1 and Aro2 had few co-links with other parties so they were also excluded from the analysis. Ultimately, 54 parties are included in the MDS analysis. The stress value of this MDS analysis is 0.03 , which is very low and suggests a very good fit between the map and the data. Figure 2 shows the MDS map.

FIG. 2. MDS map for EPP and PES political parties 
Romero-Frías, E. \& Vaughan, L. (2010). "European Political Trends Viewed Through Patterns of Web Linking”. Journal of the American Society for Information Science and Technology, 61(10): 2109-2121. Postprint for research purposes.

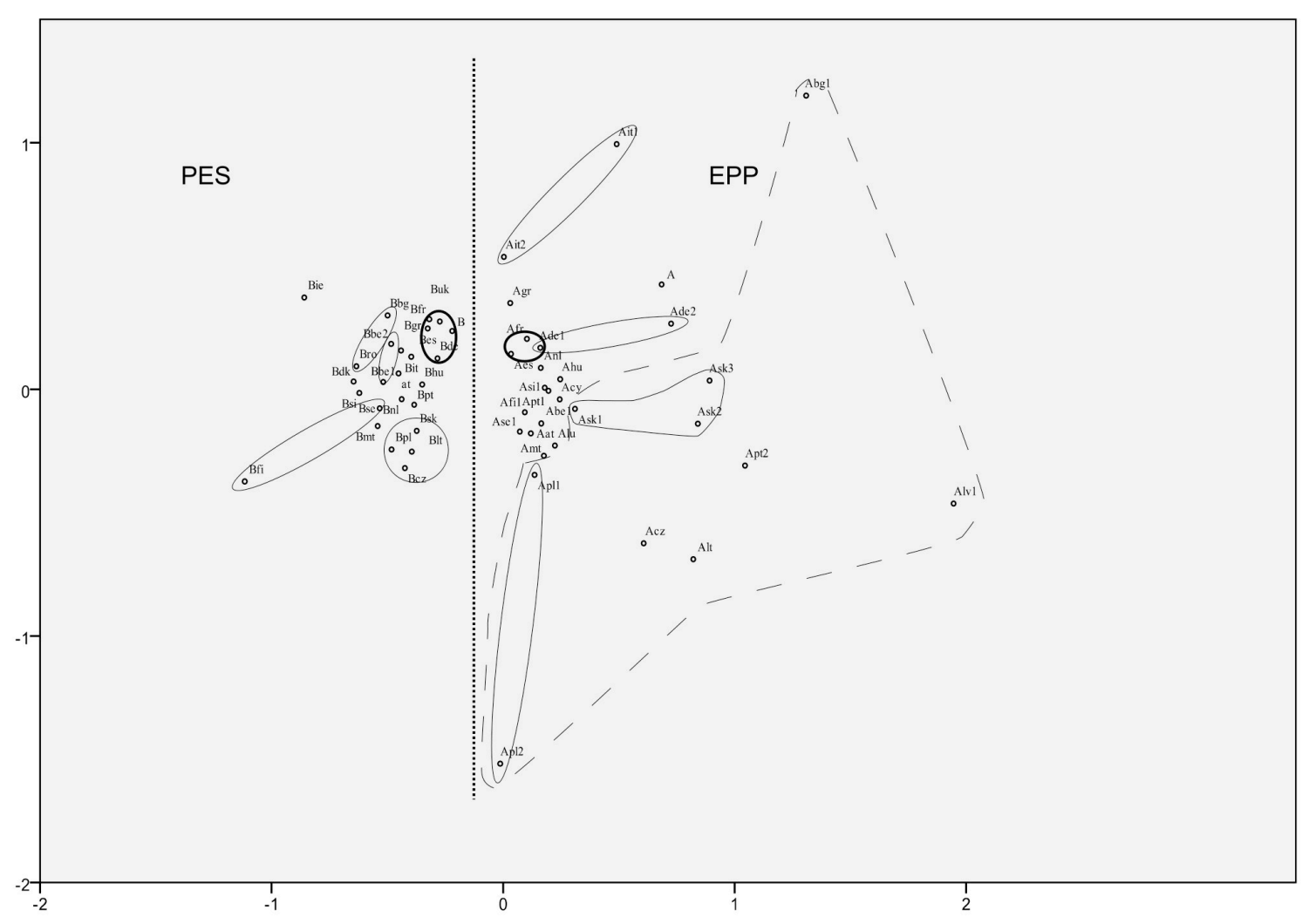

The MDS map shows, without any exception, a clear division between conservative and progressive parties. They form two distinctive clusters, although parties within each cluster are grouped differently. The cluster of left-wing parties is much tighter than that of right-wing parties. This suggests a stronger integration and homogeneity among the left. In addition, there are some other relevant clusters in the map. These are marked by bold lines and show the political core of the EU. On the left side, the British (Buk), French (Bfr), German (Bde), and Spanish (Bes) parties are in the same cluster as the PES (B). On the right side, the corresponding conservative parties (Afr, Ade1, Aes) are placed almost in a mirror position. The British Conservative party is not included in the map because it is not currently part of the EPP. The other clusters in the map show parties from the same country and region (right-wing parties: Germany, 
Romero-Frías, E. \& Vaughan, L. (2010). "European Political Trends Viewed Through Patterns of Web Linking". Journal of the American Society for Information Science and Technology, 61(10): 2109-2121. Postprint for research purposes.

Italy, Poland, Slovakia) or from neighboring countries (left-wing parties: Baltic and Eastern, Mediterranean, and Scandinavian countries).

The division between the left-wing and right-wing parties could be explained by several factors. First, left-wing parties are likely to establish more connections with civil right movements, grassroots organizations and NGOs. These organizations tend to have a strong presence on the Web and are likely to create co-links to left-wing parties. In addition, left-wing parties have traditionally supported and promoted internationalism, which translates into the creation of links with other national parties belonging to the same political family. In contrast, right-wing parties tend to be more nationalist. These two factors may explain why the degree of cohesion is lower for right-wing parties as seen in Figure 2.

However, this general explanation needs to be read in light of the countries' different historical and political histories. Probably the most prominent factor that determines departures from this general trend is the distinction between formerly communist countries and countries without a communist heritage. In former communist countries, the reaction against left-wing ideas and the communist heritage of many new social democrat parties make right-wing parties more attractive. In an attempt to compensate for this weakness, left-wing parties may tend to claim their European roots by approaching the political core of the EU in order to gain legitimacy. In contrast, right-wing parties do not need to build these European linkages with other conservative national parties; therefore the nationalist component is more significant. For example, Poland and the Czech Republic, both former communist countries with conservative leaders, demonstrated a reluctance to sign the Lisbon Treaty.

The difference between the former communist countries and other countries is also revealed in Figure 2. As shown by the area with dashed line, some right-wing parties in former communist countries are located in a fringe position, far from the center of the map. This cluster has only a few exceptions: a Portuguese party is included in this area (Apt2) while the Hungarian (Ahu) and Slovenian (Asi) parties are not. This pattern of seeing parties from former communist countries located on the fringes of the map 
Romero-Frías, E. \& Vaughan, L. (2010). "European Political Trends Viewed Through Patterns of Web Linking”. Journal of the American Society for Information Science and Technology, 61(10): 2109-2121. Postprint for research purposes.

is also visible on the left side of the map, although the effect is less pronounced. Parties from the Czech Republic, Lithuania, Poland and Slovakia form a cluster in the lower part of the map while parties from Bulgary, Hungary and Romania are located in the upper part of the map. Both clusters are tighter than the cluster on the right.

Finally, the roles of the political parties at the European level are also different, as is reflected in their positions in the map. PES (B) is in a more central position than EPP (A), which may be a result of PES's intense and proactive work in recent years organizing gatherings not only among party members but also with European activists. For example, PES organized an active online campaign to prepare for the June 2009 European elections. This campaign, known as "Manifesto 2009," began in October 2007 with the aim of engaging activists from all over Europe to provide ideas for the manifesto in the elections. The campaign was based on a Web platform hosted on the pes.org domain and combined a complete set of Web 2.0 tools (e.g., YouTube, Vimeo, Facebook, Twitter, Flickr, and MySpace, among others) to coordinate actions and promote debates.. Four languages, English, French, German and Spanish, were used in the campaign, especially the first two. This dynamic e-campaign could explain why, in Figure 2, the PES group forms a tighter cluster than the EPP group and also why the position of the social democrat European party is more central than that of the conservative party.

\subsection{Comparison of inlink counts}

Results from Figures 1 and 2 showed that the two factors affecting Web co-link patterns are: political orientation (left vs. right) and political history (whether or not a the country is a former communist country). We further analyzed inlink counts by a two-way analysis of variance test to determine if these two factors are significant. The original data are presented in Table 4. Germany is excluded from this analysis as only part of the country can be considered to be formerly communist. The dependent variable of the test is the number of inlinks and the two independent variables are type of party (EPP vs. PES) and the country's political history (formerly communist or not). The test showed that the country's political 
Romero-Frías, E. \& Vaughan, L. (2010). "European Political Trends Viewed Through Patterns of Web Linking”. Journal of the American Society for Information Science and Technology, 61(10): 2109-2121. Postprint for research purposes.

history is indeed a significant factor $(\mathrm{p}=0.01)$. As shown in Figure 3, right-wing parties are more popular in the former communist countries while left-wing parties are more popular in countries without a history of communism. The difference between EPP and PES is not statistically significant $(\mathrm{p}=0.26)$, nor is the interaction between political history and political orientation $(\mathrm{p}=0.20)$. This conclusion makes sense given that the EPP and PES have the opposite online popularity in the two types of countries. Their popularity, as measured by the inlink count, is not significantly different when the two types of country (formerly communist or not) are combined in the analysis.

FIG. 3. Inlink count comparison by party and country

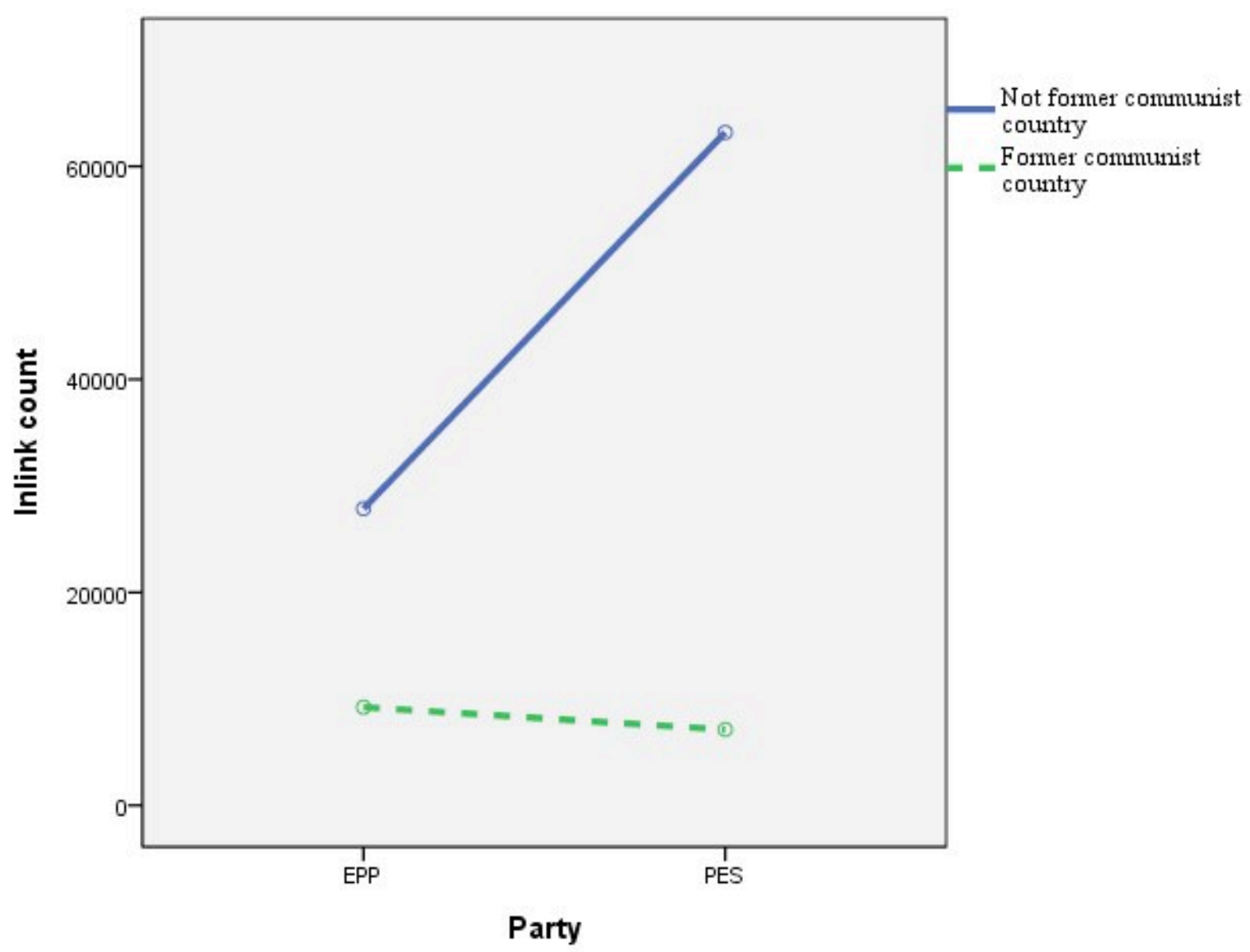


Romero-Frías, E. \& Vaughan, L. (2010). "European Political Trends Viewed Through Patterns of Web

Linking". Journal of the American Society for Information Science and Technology, 61(10): 2109-2121. Postprint for research purposes.

Table 4. Comparison of inlink counts based on former vs non former communist countries

\begin{tabular}{|c|c|c|c|c|}
\hline Political party & Country & $\begin{array}{l}\text { Inlink } \\
\text { count }\end{array}$ & $\begin{array}{c}\text { Party } \\
\text { affiliation }\end{array}$ & $\begin{array}{c}\text { Former } \\
\text { communism }\end{array}$ \\
\hline Socialist Party & France & 285000 & PES & no \\
\hline The Labour Party & UK & 180000 & PES & no \\
\hline Spanish Socialist Workers' Party & Spain & 177000 & PES & no \\
\hline Partido Popular & Spain & 127000 & EPP & no \\
\hline Union pour un Mouvement populaire & France & 120000 & EPP & no \\
\hline Dutch Labour Party & Netherlands & 81400 & PES & no \\
\hline The Swedish Social Democratic Party & Sweden & 41600 & PES & no \\
\hline Social Democratic Party of Austria & Austria & 39400 & PES & no \\
\hline Moderata Samlingspartiet & Sweden & 38300 & EPP & no \\
\hline $\begin{array}{l}\text { Fidesz - Magyar Polgári Szövetség, } \\
\text { Kereszténydemokrata Néppárt }\end{array}$ & Hungary & 37400 & EPP & yes \\
\hline Panhellenic Socialist Movement & Greece & 31100 & PES & no \\
\hline Democratic Left & Italy & 30700 & PES & no \\
\hline Il Popolo della Libertà & Italy & 30500 & EPP & no \\
\hline Christen Democratisch Appel & Netherlands & 29900 & EPP & no \\
\hline Platforma Obywatelska RP & Poland & 27500 & EPP & yes \\
\hline Österreichische Volkspartei & Austria & 22700 & EPP & no \\
\hline Social Progressive Alternative & Belgium & 21800 & PES & no \\
\hline Danish Social Democratic Party & Denmark & 18200 & PES & no \\
\hline Christen-Democratisch \& Vlaams & Belgium & 17200 & EPP & no \\
\hline Socialist Party & Belgium & 16400 & PES & no \\
\hline Czech Social Democratic & Czech Republic & 13900 & PES & yes \\
\hline New Democracy & Greece & 12200 & EPP & no \\
\hline Labour Party & Ireland & 11500 & PES & no \\
\hline Socialist Party & Portugal & 11500 & PES & no \\
\hline Partit Nazzjonalista & Malta & 11200 & EPP & no \\
\hline Hungarian Socialist Party & Hungary & 11200 & PES & yes \\
\hline $\begin{array}{l}\text { Kansallinen Kokoomus r.p. / } \\
\text { Samlingspartiet r.p. }\end{array}$ & Finland & 10900 & EPP & no \\
\hline $\begin{array}{l}\text { Strana mad'arskej koalície - Magyar } \\
\text { Koalíció Pártja }\end{array}$ & Slovakia & 10500 & EPP & yes \\
\hline $\begin{array}{l}\text { Unione dei Democratici Cristiani e } \\
\text { Democratici di Centro }\end{array}$ & Italy & 10400 & EPP & no \\
\hline $\begin{array}{l}\text { Uniunea Democrată Maghiară din } \\
\text { România }\end{array}$ & Romania & 10400 & EPP & yes \\
\hline $\begin{array}{l}\text { Křest’anská a demokratická unie - } \\
\text { Československá strana lidová }\end{array}$ & Czech Republic & 9380 & EPP & yes \\
\hline $\begin{array}{l}\text { Sojusz Lewicy Demokratycznej - Unia } \\
\text { Pracy }\end{array}$ & Poland & 8050 & PES & yes \\
\hline Socialdemocracy & Slovakia & 7700 & PES & yes \\
\hline Partido Social Democrata PPD/PSD & Portugal & 7480 & EPP & no \\
\hline $\begin{array}{l}\text { Citizens for European Development of } \\
\text { Bulgaria }\end{array}$ & Bulgaria & 5870 & EPP & yes \\
\hline Social Democratic Party & Romania & 5870 & PES & yes \\
\hline Slovenska Demokratska Stranka & Slovenia & 4690 & EPP & yes \\
\hline
\end{tabular}


Romero-Frías, E. \& Vaughan, L. (2010). "European Political Trends Viewed Through Patterns of Web

Linking". Journal of the American Society for Information Science and Technology, 61(10): 2109-2121. Postprint for research purposes.

\begin{tabular}{|l|l|r|r|r|} 
Polskie Stronnictwo Ludowe & Poland & 4530 & EPP & yes \\
\hline $\begin{array}{l}\text { Lithuanian Social Democratic Workers' } \\
\text { Party }\end{array}$ & Lithuania & 4280 & PES & yes \\
\hline Partido Popular CDS/PP & Portugal & 4230 & EPP & no \\
\hline $\begin{array}{l}\text { Tévynės sajunga - Lietuvos krikščionys } \\
\text { demokratai }\end{array}$ & Lithuania & 3840 & EPP & yes \\
\hline Social Democrats & Slovenia & 3040 & PES & yes \\
\hline Coalition for Bulgaria & Bulgaria & 2940 & PES & yes \\
\hline $\begin{array}{l}\text { Slovenská demokratická a krest'anská } \\
\text { únia - Demokratická strana }\end{array}$ & Slovakia & 2040 & EPP & yes \\
\hline Krestanskodemokratické hnutie & Slovakia & 1990 & EPP & yes \\
\hline Labour Party & Malta & 1600 & PES & no \\
\hline Chrëschtlech Sozial Vollekspartei & Luxemburg & 1580 & EPP & no \\
\hline Democratic Rally of Cyprus & Cyprus & 1430 & EPP & no \\
\hline Partidul Democrat Liberal & Romania & 1320 & EPP & yes \\
\hline Fine Gael & Ireland & 833 & EPP & no \\
\hline Social Democratic Party of Finland & Finland & 668 & PES & no \\
\hline Pilsoniska Savieniba & Latvia & 402 & EPP & yes \\
\hline
\end{tabular}

\section{Discussion and Conclusions}

The study has shown a clear difference between left-wing and right-wing parties in Web presence. The MDS maps generated from Web co-link data reflect Europe's political trends. Ideology seems to be the main factor in the clustering of political parties, followed by country or regional affiliation. This clustering pattern based on ideology could be explained a result of replication of Web production practices on a global scale (Foot et al., 2009). Also, visitors to political sites are typically already politically active (Gibson et al., 2003, 2005; Norris, 2003). Consequently, political Websites may be of limited use in reaching the majority of voters, which could explain why the greater Web presence of the left-wing parties in the EP did not translate into a higher number of seats in the 2009 election.

The results show a distinct Web linking pattern based on the political history of the country (whether it is a former communist country). This Web linking pattern reflects political trends in countries in which conservative governments are in power and right-wing ideology is currently more attractive. These trends could be considered a reaction against communist political heritage. By contrast, in countries without a 
Romero-Frías, E. \& Vaughan, L. (2010). "European Political Trends Viewed Through Patterns of Web Linking”. Journal of the American Society for Information Science and Technology, 61(10): 2109-2121. Postprint for research purposes.

communist heritage, Websites of social democrat parties are more inlinked than Websites of conservative parties, irrespective of which party is in power.

The influence of Web 2.0 on Internet politics (Chadwick \& Howard, 2009) needs to be taken into account because of its potential impact on linking patterns. Ward and Gibson (2009) point out that one positive effect of online channels is the creation of stronger links between an organization and its supporters and between organizational supporters. Ward and Gibson are referring to offline ties but we believe that online links are also created. This effect is especially significant in the context of our study as the creation of political content on the Web is often accompanied by the creation of links, which increases the likelihood that Web data will more accurately reflect offline political patterns. This in return makes link analysis increasingly useful in analyzing political trends.

In order to understand the findings of our study properly, the limitations of the study must be acknowledged. As noted in section 4.2, we were able to use only one search engine for data collection because of the state of major search engines at the time of the study. Different search engines provide different Web coverage (Vaughan \& Zhang, 2007), so the result from a single search engine may not be as reliable as a result from multiple search engines. Future studies should consider using multiple search engines for data collection if possible. An additional problem is the potential for measurement errors in commercial search engines, as earlier studies have pointed out (e.g. Bar-Ilan, 2004, 2005). These errors make studies based on quantitative data from search engines vulnerable. Qualitative studies could help to determine the nature of the limitations of the current study as well as provide insight into the motivations behind Web links. This kind of qualitative studies have been carried out for other types of Websites, including academic (Thelwall, 2003) and business Websites (Vaughan, Kipp \& Gao, 2007), but not the Websites of political parties. Further research is needed in this area. 
Romero-Frías, E. \& Vaughan, L. (2010). "European Political Trends Viewed Through Patterns of Web Linking”. Journal of the American Society for Information Science and Technology, 61(10): 2109-2121. Postprint for research purposes.

A methodological issue of data analysis needs to be discussed. The study used MDS for data analysis but MDS is not the only statistical method that can be used to generate clusters. Cluster analysis is an alternative method. To compare the two methods, we ran cluster analysis on the two data sets used to generate Figures 1 and 2. The clusters generated from the cluster analysis did not match very well the clusters in the MDS maps. The advantage of cluster analysis is that it requires less human judgment than MDS. However, this could also be a disadvantage because the method is more data-driven than theorydriven. When theoretically meaningful clusters are not clearly delineated (i.e., when neighboring clusters are not far apart, as is the case in this study), cluster analysis results in clusters that fit the data but are not theoretically meaningful. There are many interrelated factors affecting the positions of political parties and we believe this to be the main reason that the clusters in the MDS maps (Fig. 1 and Fig. 2) are not far apart. MDS is more effective than cluster analysis in this situation because it is both data-driven (the MDS maps are generated from the data) and theory-driven (human interpretation of the maps), and provides better visualization of the data.

This study used an innovative method to investigate European politics and offered some insights into political trends by exploiting Web hyperlink data. The work focused on an overall analysis of European political parties and therefore presents many possibilities for analyzing political issues at both the European and national levels. The diverse variables that are likely to affect the parties' positions in the political spectrum are complex. Future research could examine variables not considered in this study, such as language. Some earlier studies have analyzed the linguistic variable (Thelwall, Tang \& Price, 2003; Vaughan, 2006) and found it to be a significant factor. The dominance of the English language could play a role in political sites. The impact of Web 2.0 on the link structure that interconnects political parties could be studied using content analysis, particularly to test whether or not the types of Webpages that co-link or inlink parties differ based on a party's ideology. In addition, a longitudinal study could test the feasibility of using link analysis to monitor political evolution in the European Union. Finally, in- 
Romero-Frías, E. \& Vaughan, L. (2010). "European Political Trends Viewed Through Patterns of Web Linking”. Journal of the American Society for Information Science and Technology, 61(10): 2109-2121. Postprint for research purposes.

depth analysis could be carried out to examine unusual cases of Web presence, such as the Italian parties, which do not appear in central positions in the MDS maps generated in the current study, despite the relative importance of the country in European politics. One potential explanation for this situation is the continual change to Italian party websites as a result of political instability. For example, the Website of Ait1 (the party of the Italian prime minister) appears for the first time in the Internet Archive only in April 2008.

\section{Acknowledgement}

The second author is supported by a research grant on from the Social Sciences and Humanities Research Council of Canada (SSHRC). Comments and suggestions provided by anonymous referees helped strengthen the paper and are greatly appreciated.

\section{References}

Bar-Ilan, J. (2005). Expectations versus reality - Search engine features needed for Web research at mind. Cybermetrics, 9(1), paper 2.

Bar-Ilan, J. (2004). The use of Web search engines in information science research. Annual Review of Information Science and Technology, 38, 231-288.

Bar-Ilan, J. \& Echerman, A. (2005). The anthrax scare and the Web: A content analysis of Web pages linking to resources on anthrax. Scientometrics, 63(3), 443-462.

Burt, E., \& Taylor, J. (2001). When 'virtual' meets values: insights from the voluntary sector. Information, Communication and Society, 4(1), 54-73.

Chadwick, A., \& Howard, P.N. (2009). Introduction. New directions in internet politics research. In A. Chadwick \& P.N. Howard (Eds.), Routledge Handbook of Internet Politics (pp. 1-9). New York: Routledge. 
Romero-Frías, E. \& Vaughan, L. (2010). "European Political Trends Viewed Through Patterns of Web Linking”. Journal of the American Society for Information Science and Technology, 61(10): 2109-2121. Postprint for research purposes.

Davis, R., Owen, D., Taras, D., \& Ward, S.J. (2008). Making a Difference? The internet and elections in comparative perspective. Lanham, MD: Lexington Books.

Etzkowitz, H., \& Leydesdorff, L. (1997). Universities and the Global Knowledge Economy: A Triple Helix of University-Industry-Government Relations. London: Pinter.

European Parliament (2009). European Parliament Website, available at: http://www.europarl.europa.eu/ (accessed 2 November 2009).

European Union (2009). European Union Website, available at: http://europa.eu/ (accessed 2 November 2009).

Foot, K.A., Xenos, M., Schneider, S.M., Kluver, R., \& Jankowski, N.W. (2009). Electoral web production practices in cross-national perspective. The relative influence of national development, political culture, and web genre. In A. Chadwick \& P.N. Howard (eds.), Routledge Handbook of Internet Politics (pp. 40-55). New York: Routledge.

Gao, Y. (2009). Gauging Public Interest from Server Logs, Surveys and Inlinks: A Multi-method Approach to Analyze News Websites. PhD dissertation. University of Western Ontario, Canada.

García-Santiago, L., \& de Moya-Anegón, F. (2009). Using co-outlinks to mine heterogeneous networks. Scientometrics, 79(3), 681-702.

Gibson, R.K., Lusoli, W., \& Ward, S.J. (2003). The internet and political campaigning: the new medium comes of age? Representation, 39(3), 166-80.

Gibson, R.K., Lusoli, W., \& Ward, S.J. (2005). Online participation in the UK: testing a contextualised model of internet effects. British Journal of Politics and International Relations, 7(4), 561-83.

Google (2006). “Google SOAP Search API Reference”, available at: http://www.google.com/apis/reference.html\#2_2 (accessed 3 June 2009). 
Romero-Frías, E. \& Vaughan, L. (2010). "European Political Trends Viewed Through Patterns of Web

Linking". Journal of the American Society for Information Science and Technology, 61(10): 2109-2121. Postprint for research purposes.

Google (2009). "Links to your site", available at:

http://www.google.com/support/webmasters/bin/answer.py?hl=en\&answer=55281 (accessed 3 June 2009).

Holmberg, K. J. (2009). Webometric network analysis: Mapping cooperation and geopolitical connections between local government administration on the Web. $\mathrm{PhD}$ dissertation, Åbo Akademi University, Finland.

Kluver, J., Jankowski, N.W., Foot, K.A., \& Schneider, S.M. (Eds.) (2007). The Internet and National Elections: a comparative study of web campaigning. New York: Routledge.

Leydesdorff, L., \& Meyer, M. (2003). The triple helix of university-industry-government relations. Scientometrics, 58(2), 191-203.

Leydesdorff, L., \& Meyer, M. (2007). The scientometrics of a triple helix of university-industrygovernment relations: Introduction to the topical issue. Scientometrics, 70(2), 207-222.

Live Search (2007). "We are flattered, but...", available at:

http://www.bing.com/community/blogs/search/archive/2007/03/28/we-are-flattered-but.aspx (accessed 3 June 2009).

March, L. (2006). Virtual parties in a virtual world: Russian parties and the political internet. In S. Oates, D.M. Owen \& R.K. Gibson (eds.), The Internet and Politics: citizens, voters, and activists. London: Routledge.

Norris (2003). Preaching to the converted? Pluralism, participation and party websites. Party politics, $9(1), 21-46$.

Stuart, D., \& Thelwall, M. (2006). Investigating triple helix relationships using URL citations: a case study of the UK West Midlands automobile industry. Research Evaluation, 15(2), 97-106. 
Romero-Frías, E. \& Vaughan, L. (2010). "European Political Trends Viewed Through Patterns of Web

Linking”. Journal of the American Society for Information Science and Technology, 61(10): 2109-2121. Postprint for research purposes.

Thelwall, M., Tang, R., \& Price, E. (2003). Linguistic patterns of academic web use in Western Europe. Scientometrics, 56(3), 417-432.

Thelwall, M., \& Vaughan, L. (2004). A fair history of the Web? Examining country balance in the Internet archive. Library \& Information Science Research, 26(2), 162-176.

Thelwall, M. \& Wilkinson, D. (2004). Finding similar academic Web sites with links, bibliometric couplings and colinks. Information Processing and Management, 40, 94-101.

Thelwall, M. (2003). What is this link doing here? Beginning a fine-grained process of identifying reasons for academic hyperlink creation. Information Research, 8(3) paper no. 151, available at: http://informationr.net/ir/8-3/paper151.html

van Dijk, J.A.G.M. (2009). One Europe, digitally divided. In A. Chadwick \& P.N. Howard (Eds.), Routledge Handbook of Internet Politics (pp. 288-304). New York: Routledge.

Vaughan, L. (2006). Visualizing Linguistic and Cultural Differences Using Web Co-Link Data. Journal of the American Society for Information Science and Technology, 57(9), 1178-1193.

Vaughan, L., \& Thelwall, M. (2004). Search engine coverage bias: Evidence and possible causes. Information Processing \& Management, 40(4), 693-707.

Vaughan, L., \& You, J. (2006). Comparing business competition positions based on Web co-link data: The global market vs. the Chinese market. Scientometrics, 68(3), 611-628.

Vaughan, L., \& You, J. (2008). Content assisted web co-link analysis for competitive intelligence. Scientometrics, 77(3), 433-444.

Vaughan, L., \& Zhang, Y. (2007). Equal representation by search engines? A comparison of Websites across countries and domains. Journal of Computer-Mediated Communication, 12(3), available at http://jcmc.indiana.edu:80/vol12/issue3/vaughan.html 
Romero-Frías, E. \& Vaughan, L. (2010). "European Political Trends Viewed Through Patterns of Web Linking". Journal of the American Society for Information Science and Technology, 61(10): 2109-2121. Postprint for research purposes.

Vaughan, L., Kipp, M., \& Gao, Y. (2007). Are co-linked business Websites really related? A link classification study. Online Information Review, 31(4), 440-450.

Ward, S., \& Gibson, R. (2009). European political organizations and the internet. In A. Chadwick \& P.N. Howard (Eds.), Routledge Handbook of Internet Politics (pp. 25-39). New York: Routledge.

Appendix A. EPP political parties

\begin{tabular}{|c|c|c|c|c|c|c|}
\hline Label & URL & $\begin{array}{l}\text { Abbre- } \\
\text { viation }\end{array}$ & Name & Country & Seats & linkdomain \\
\hline A & http://www.epp.eu & EPP & European Popular Party & Europe & 265 & 97400 \\
\hline Ade1 & http://www.cdu.de & $\mathrm{CDU}$ & $\begin{array}{l}\text { Christlich Demokratische } \\
\text { Union Deutschlands }\end{array}$ & Germany & 34 & 221000 \\
\hline Afr & http://www.u-m-p.org & UMP & $\begin{array}{l}\text { Union pour un Mouvement } \\
\text { populaire }\end{array}$ & France & 29 & 120000 \\
\hline Ait1 & http://www.ilpopolodellaliberta.it & PdL & Il Popolo della Libertà & Italy & 29 & 30500 \\
\hline Apl1 & http://www.platforma.org/ & PO & Platforma Obywatelska RP & Poland & 25 & 27600 \\
\hline Aes & http://www.pp.es/ & PP & Partido Popular & Spain & 23 & 127000 \\
\hline Ahu & http://www.fidesz.hu & $\begin{array}{l}\text { FIDESZ } \\
- \text { KDNP }\end{array}$ & $\begin{array}{l}\text { Fidesz - Magyar Polgári } \\
\text { Szövetség, } \\
\text { Kereszténydemokrata Néppárt }\end{array}$ & Hungary & 14 & 37400 \\
\hline Aro1 & http://www.pdl.org.ro & PD-L & Partidul Democrat Liberal & Romania & 10 & 491 \\
\hline Agr & http://www.nd.gr & ND & New Democracy & Greece & 8 & 12200 \\
\hline Apt1 & http://www.psd.pt & PPD/PSD & $\begin{array}{l}\text { Partido Social Democrata } \\
\text { PPD/PSD }\end{array}$ & Portugal & 8 & 7480 \\
\hline Ade2 & http://www.csu.de & CSU & $\begin{array}{l}\text { Christlich Soziale Union } \\
\text { Deutschlands }\end{array}$ & Germany & 8 & 27600 \\
\hline Aat & http://www.oevp.at & ÖVP & Österreichische Volkspartei & Austria & 6 & 23000 \\
\hline Anl & http://www.cda.nl & $\mathrm{CDA}$ & Christen Democratisch Appel & Netherlands & 5 & 29900 \\
\hline Ait2 & http://www.udc-italia.it & UDC & $\begin{array}{l}\text { Unione dei Democratici } \\
\text { Cristiani e Democratici di }\end{array}$ & Italy & 5 & 10400 \\
\hline
\end{tabular}


Romero-Frías, E. \& Vaughan, L. (2010). "European Political Trends Viewed Through Patterns of Web Linking". Journal of the American Society for Information Science and Technology, 61(10): 2109-2121. Postprint for research purposes.

\begin{tabular}{|c|c|c|c|c|c|c|}
\hline & & & Centro & & & \\
\hline $\operatorname{Abg} 1$ & http://www.gerb.bg & GERB & $\begin{array}{l}\text { Citizens for European } \\
\text { Development of Bulgaria }\end{array}$ & Bulgaria & 5 & 5900 \\
\hline Aie & http://www.finegael.org & FG & Fine Gael & Ireland & 4 & 835 \\
\hline Alt & http://www.tsajunga.lt & TS-LKD & $\begin{array}{l}\text { Tèvynès sajunga - Lietuvos } \\
\text { krikščionys demokratai }\end{array}$ & Lithuania & 4 & 3840 \\
\hline Ase1 & http://www.moderat.se & M & Moderata Samlingspartiet & Sweden & 4 & 38400 \\
\hline Apl2 & http://www.psl.pl & PSL & Polskie Stronnictwo Ludowe & Poland & 3 & 4510 \\
\hline Abe 1 & http://www.cdenv.be & $\mathrm{CD} \& \mathrm{~V}$ & $\begin{array}{l}\text { Christen-Democratisch \& } \\
\text { Vlaams }\end{array}$ & Belgium & 3 & 17200 \\
\hline Alu & http://www.csv.lu & CSV & $\begin{array}{l}\text { Chrëschtlech Sozial } \\
\text { Vollekspartei }\end{array}$ & $\begin{array}{l}\text { Luxembour } \\
\mathrm{g}\end{array}$ & 3 & 1570 \\
\hline Afil & http://www.kokoomus.fi & KOK & $\begin{array}{l}\text { Kansallinen Kokoomus r.p. / } \\
\text { Samlingspartiet r.p. }\end{array}$ & Finland & 3 & 10900 \\
\hline Aro2 & http://www.udmr.ro & UDMR & $\begin{array}{l}\text { Uniunea Democrată Maghiară } \\
\text { din România }\end{array}$ & Romania & 3 & 6000 \\
\hline Amt & http://www.pn.org.mt & $\mathrm{PN}$ & Partit Nazzjonalista & Malta & 2 & 11300 \\
\hline Acz & http://www.kdu.cz & $\begin{array}{l}\text { KDU- } \\
\text { ČSL }\end{array}$ & $\begin{array}{l}\text { Křest’anská a demokratická } \\
\text { unie - Československá strana } \\
\text { lidová }\end{array}$ & $\begin{array}{l}\text { Czech } \\
\text { Republic }\end{array}$ & 2 & 9420 \\
\hline Apt2 & http://www.cds.pt & CDS-PP & Partido Popular CDS/PP & Portugal & 2 & 4230 \\
\hline Asi1 & http://www.sds.si & SDS & $\begin{array}{l}\text { Slovenska Demokratska } \\
\text { Stranka }\end{array}$ & Slovenia & 2 & 4710 \\
\hline Ask3 & http://www.kdh.sk & $\mathrm{KDH}$ & $\begin{array}{l}\text { Krest'anskodemokratické } \\
\text { hnutie }\end{array}$ & Slovakia & 2 & 1990 \\
\hline Ask1 & http://www.sdkuonline.sk & $\begin{array}{l}\text { SDKÚ - } \\
\text { DS }\end{array}$ & $\begin{array}{l}\text { Slovenská demokratická a } \\
\text { krest’anská únia - } \\
\text { Demokratická strana }\end{array}$ & Slovakia & 2 & 2040 \\
\hline Acy & http://www.disy.org.cy & DISY & Democratic Rally of Cyprus & Cyprus & 2 & 1430 \\
\hline Alv1 & http://www.pilsoniska-savieniba.lv & PS & Pilsoniska Savieniba & Latvia & 2 & 401 \\
\hline Ask2 & http://www.mkp.sk & $\begin{array}{l}\text { SMK- } \\
\text { MPK }\end{array}$ & $\begin{array}{l}\text { Strana mad’arskej koalície - } \\
\text { Magyar Koalíció Pártja }\end{array}$ & Slovakia & 2 & 10600 \\
\hline
\end{tabular}


Romero-Frías, E. \& Vaughan, L. (2010). "European Political Trends Viewed Through Patterns of Web Linking". Journal of the American Society for Information Science and Technology, 61(10): 2109-2121. Postprint for research purposes.

\begin{tabular}{|l|l|l|l|l|r|r|} 
Abg2 & http://www.dsb.bg & $\begin{array}{l}\text { SDS- } \\
\text { DSB }\end{array}$ & Blue Coalition & Bulgaria & 1 & 4820 \\
\hline Abe2 & http://www.lecdh.be & cdH & Centre Démocrate Humaniste & Belgium & 1 & 8840 \\
\hline Asi2 & http://www.nsi.si & N.Si & $\begin{array}{l}\text { Nova Slovenija - Krščanska } \\
\text { Ljudska Stranka }\end{array}$ & Slovenia & 1 & 1550 \\
\hline Adk & http://www.konservative.dk & C & Det Konservative Folkeparti & Denmark & 1 & 10400 \\
\hline Aee & http://www.irl.ee & IRL & Isamaa ja Res Publica Liit & Estonia & 1 & 8980 \\
\hline Aro3 & http://www.elenabasescu.net & Băsescu & Băsescu Elena & Romania & 1 & 700 \\
\hline Ase2 & http://www.kristdemokraterna.se & KD & Kristdemokraterna & Sweden & 1 & 12700 \\
\hline Abe3 & http://www.csp-dg.be & CSP & Christlich Soziale Partei & Belgium & 1 & 870 \\
\hline Afi2 & http://www.kristillisdemokraatit.fi & KD-PS & Vaaliliitossa - i Valförbund & Finland & 1 & 1180 \\
\hline Alv2 & http://www.jaunaislaiks.lv & JL & Jaunais laiks (New Era) & Latvia & 1 & 519 \\
\hline Ait3 & http://www.svpartei.org & SVP & Südtiroler Volkspartei & Italy & 1 & 2110 \\
\hline
\end{tabular}

Appendix B. PES political parties

\begin{tabular}{|l|l|l|l|l|r|r|}
\hline Label & \multicolumn{1}{|c|}{ URL } & $\begin{array}{l}\text { Abbre- } \\
\text { viation }\end{array}$ & \multicolumn{1}{|c|}{ Name } & Country & Seats & $\begin{array}{c}\text { link- } \\
\text { domain }\end{array}$ \\
\hline B & http://www.pes.org & PES & Party of European Socialists & Europe & 184 & 160000 \\
\hline Bde & http://www.spd.de & SPD & $\begin{array}{l}\text { Social Democratic Party of } \\
\text { Germany }\end{array}$ & Germany & 23 & 735000 \\
\hline Bes & http://www.psoe.es & PSOE & Spanish Socialist Workers' Party & Spain & 21 & 177000 \\
\hline Bit & http://www.dsonline.it & PD & Democratic Left & Italy & 21 & 30800 \\
\hline Bfr & http://www.parti-socialiste.fr & PS-f & Socialist Party (France) & France & 14 & 232000 \\
\hline Buk & http://www.labour.org.uk & $\begin{array}{l}\text { Lab } \\
\text { (UK) }\end{array}$ & The Labour Party (UK) & $\begin{array}{l}\text { United } \\
\text { Kingdom }\end{array}$ & 13 & 170000 \\
\hline Bro & http://www.psd.ro & PSD & $\begin{array}{l}\text { Social Democratic Party } \\
\text { (Romania) }\end{array}$ & Romania & 11 & 5890 \\
\hline Bgr & http://www.pasok.gr & $\begin{array}{l}\text { PASO } \\
\text { K }\end{array}$ & Panhellenic Socialist Movement & Greece & 8 & 31100 \\
\hline Bcz & http://www.cssd.cz & CSSD & Czech Social Democratic & $\begin{array}{l}\text { Czech } \\
\text { Republic }\end{array}$ & 7 & 13900 \\
\hline
\end{tabular}


Romero-Frías, E. \& Vaughan, L. (2010). "European Political Trends Viewed Through Patterns of Web Linking". Journal of the American Society for Information Science and Technology, 61(10): 2109-2121. Postprint for research purposes.

\begin{tabular}{|c|c|c|c|c|c|c|}
\hline Bpt & http://www.ps.pt & PS & Socialist Party (Portugal) & Portugal & 7 & 6800 \\
\hline Bpl & http://www.sld.org.pl & $\begin{array}{l}\text { SLD- } \\
\text { UP }\end{array}$ & $\begin{array}{l}\text { Sojusz Lewicy Demokratycznej } \\
\text { - Unia Pracy }\end{array}$ & Poland & 7 & 8090 \\
\hline Bsk & http://www.strana-smer.sk & SMER & Socialdemocracy & Slovakia & 5 & 7010 \\
\hline Bse & http://www.socialdemokraterna.se & $\mathrm{S}$ & $\begin{array}{l}\text { The Swedish Social Democratic } \\
\text { Party }\end{array}$ & Sweden & 5 & 41700 \\
\hline Bdk & http://www.socialdemokraterne.dk & A & Danish Social Democratic Party & Denmark & 4 & 18200 \\
\hline Bat & http://www.spoe.at & SPÖ & $\begin{array}{l}\text { Social Democratic Party of } \\
\text { Austria }\end{array}$ & Austria & 4 & 39500 \\
\hline $\mathrm{Bbg}$ & http://www.bsp.bg & BSP & Coalition for Bulgaria & Bulgaria & 4 & 2950 \\
\hline Bhu & http://www.mszp.hu & MSZP & Hungarian Socialist Party & Hungary & 4 & 5980 \\
\hline Bie & http://www.labour.ie & Lab & Labour Party & Ireland & 3 & 11500 \\
\hline Bmt & http://www.mlp.org.mt & $\begin{array}{l}\mathrm{PL} \\
(\mathrm{MLP})\end{array}$ & Labour Party & Malta & 3 & 1600 \\
\hline Bbe2 & http://www.ps.be & PS-b & Socialist Party (Belgium) & Belgium & 3 & 9440 \\
\hline Blt & http://www.lsdp.lt & LSDP & $\begin{array}{l}\text { Lithuanian Social Democratic } \\
\text { Workers' Party }\end{array}$ & Lithuania & 3 & 4290 \\
\hline Bnl & http://www.pvda.nl & PVDA & Dutch Labour Party & $\begin{array}{l}\text { Netherland } \\
\mathrm{s}\end{array}$ & 3 & 81400 \\
\hline Bsi & http://www.socialnidemokrati.si & SD & Social Democrats & Slovenia & 2 & 2620 \\
\hline Bfi & http://www.sosialidemokraatit.fi & SDP & $\begin{array}{l}\text { Social Democratic Party of } \\
\text { Finland }\end{array}$ & Finland & 2 & 669 \\
\hline Bbe1 & http://www.s-p-a.be & SP.A & Social Progressive Alternative & Belgium & 2 & 17400 \\
\hline Bcy2 & http://www.diko.org.cy & DIKO & Dimokratiko Komma & Cyprus & 1 & 1310 \\
\hline Blu & http://www.lsap.lu & LSAP & $\begin{array}{l}\text { Luxembourgian Socialist } \\
\text { Workers' Party }\end{array}$ & Luxemburg & 1 & 1080 \\
\hline Blv & http://www.saskanascentrs.lv & LSDSP & Saskaņas Centrs & Latvia & 1 & 1770 \\
\hline Bcy1 & http://www.edek.org.cy & EAEK & $\begin{array}{l}\text { Movement of Socialdemocrats } \\
\text { EDEK }\end{array}$ & Cyprus & 1 & 2810 \\
\hline Bee & http://www.sotsdem.ee & SDE & $\begin{array}{l}\text { Estonian Social Democratic } \\
\text { Party }\end{array}$ & Estonia & 1 & 1620 \\
\hline
\end{tabular}


Romero-Frías, E. \& Vaughan, L. (2010). "European Political Trends Viewed Through Patterns of Web Linking". Journal of the American Society for Information Science and Technology, 61(10): 2109-2121. Postprint for research purposes.

Appendix C. Other political parties

\begin{tabular}{|c|c|c|c|c|c|c|}
\hline Label & URL & $\begin{array}{l}\text { Abbre- } \\
\text { viation }\end{array}$ & Name & Country & Seats & $\begin{array}{c}\text { link- } \\
\text { domain }\end{array}$ \\
\hline $\mathrm{C}$ & http://www.alde.eu & ALDE & $\begin{array}{l}\text { Alliance of Liberals and } \\
\text { Democrats for Europe }\end{array}$ & Europe & 84 & 39000 \\
\hline Cde & http://www.liberale.de & FDP & $\begin{array}{l}\text { Freie Demokratische Partei - } \\
\text { Die Liberalen }\end{array}$ & Germany & 12 & 115000 \\
\hline Cuk & http://www.libdems.org.uk & LD & Liberal Democrats & $\begin{array}{l}\text { United } \\
\text { Kingdom }\end{array}$ & 11 & 269000 \\
\hline Cit & http://www.italiadeivalori.it & IdV-LdP & $\begin{array}{l}\text { Italia dei Valori - Lista Di } \\
\text { Pietro }\end{array}$ & Italy & 7 & 19200 \\
\hline $\mathrm{Cfr}$ & http://www.mouvementdemocrate.fr & MoDem & Mouvement Démocrate & France & 6 & 90200 \\
\hline Cbe 1 & http://www.vld.be & $\begin{array}{l}\text { Open } \\
\text { VLD }\end{array}$ & $\begin{array}{l}\text { VLD-Open Vlaamse Liberalen } \\
\text { en Democraten }\end{array}$ & Belgium & 3 & 13500 \\
\hline $\mathrm{Cn} 12$ & http://www.d66.nl & D66 & Democraten 66 & Netherlands & 3 & 40000 \\
\hline Cn11 & http://www.vvd.nl & VVD & $\begin{array}{l}\text { Volkspartij voor Vrijheid en } \\
\text { Democratie }\end{array}$ & Netherlands & 3 & 3320 \\
\hline $\mathrm{Cdk}$ & http://www.venstre.dk & $\mathrm{V}$ & $\begin{array}{l}\text { Venstre - Danmarks Liberale } \\
\text { Parti }\end{array}$ & Denmark & 3 & 5780 \\
\hline Cie1 & http://www.fiannafail.ie & FF & Fianna Fáil & Ireland & 3 & 25300 \\
\hline Cbe2 & http://www.mr.be & MR & Mouvement Réformateur & Belgium & 2 & 91700 \\
\hline Ces & http://www.ciu.cat & CiU-CpE & Coalición por Europa & Spain & 2 & 3680 \\
\hline $\mathrm{D}$ & http://www.greens-efa.org & $\begin{array}{l}\text { GREENS } \\
\text { / EFA }\end{array}$ & Greens/European Free Alliance & Europe & 55 & 68800 \\
\hline Dfr & http://www.europeecologie.fr & $\begin{array}{l}\text { Europe } \\
\text { écologie }\end{array}$ & Europe écologie & France & 14 & 36000 \\
\hline Dde & http://www.gruene.de & GRÜNE & Bündnis 90/Die Grünen & Germany & 14 & 144000 \\
\hline Dnl & http://groenlinks.nl & $\begin{array}{l}\text { GroenLin } \\
\text { ks }\end{array}$ & GroenLinks & Netherlands & 3 & 51800 \\
\hline Duk2 & http://www.snp.org & SNP & Scottish National Party & UK & 2 & 61800 \\
\hline Ddk & http://www.sf.dk & $\mathrm{F}$ & SF - Socialistisk Folkeparti & Denmark & 2 & 22900 \\
\hline Dbe1 & http://web4.ecolo.be & ECOLO & $\begin{array}{l}\text { Ecologistes Confédérés pour } \\
\text { l'Organisation de Luttes }\end{array}$ & Belgium & 2 & 5770 \\
\hline
\end{tabular}


Romero-Frías, E. \& Vaughan, L. (2010). "European Political Trends Viewed Through Patterns of Web Linking". Journal of the American Society for Information Science and Technology, 61(10): 2109-2121. Postprint for research purposes.

\begin{tabular}{|l|l|l|l|l|r|r|} 
& & & Originales & & \\
\hline Duk1 & http://www.greenparty.org.uk & Greens & The Green Party & UK & 60800 \\
\hline E & http://www.europeanreform.eu & ECR & $\begin{array}{l}\text { European Conservatives and } \\
\text { Reformists Group }\end{array}$ & Europe & 54 & 4840 \\
\hline Euk1 & http://www.conservatives.com & Cons & Conservative Party & $\begin{array}{l}\text { United } \\
\text { Kingdom }\end{array}$ & 24 & 186000 \\
\hline F & http://www.guengl.eu & $\begin{array}{l}\text { GUE/ } \\
\text { NGL }\end{array}$ & $\begin{array}{l}\text { Confederal Group of the } \\
\text { European United Left - Nordic } \\
\text { Green Left. }\end{array}$ & Europe & 35 & 18400 \\
\hline
\end{tabular}

"This is the peer reviewed version of the following article: Romero-Frías, E.; Vaughan, L. European Political Trends Viewed Through Patterns of Web Linking. Journal of the American Society for Information Science and Technology, 61(10): 2109-2121 (2010), which has been published in final form at http://dx.doi.org/10.1002/asi.21375. This article may be used for non-commercial purposes in accordance with Wiley Terms and Conditions for Self-Archiving." 